\title{
Application of Airborne Geophysical and ASTER Data for Hydrothermal Alteration Mapping in the Sar-Kuh Porphyry Copper Area, Kerman Province, Iran
}

\section{Mehdi Honarmand}

Department of Ecology, Institute of Science and High Technology and Environmental Sciences, Graduate University of Advanced Technology, Kerman, Iran

Email: mehonarmand167@yahoo.com

How to cite this paper: Honarmand, M. (2016) Application of Airborne Geophysical and ASTER Data for Hydrothermal Alteration Mapping in the Sar-Kuh Porphyry Copper Area, Kerman Province, Iran. Open Journal of Geology, 6, 1257-1268.

http://dx.doi.org/10.4236/ojg.2016.610092

Received: August 18, 2016

Accepted: October 4, 2016

Published: October 7, 2016

Copyright $\odot 2016$ by author and Scientific Research Publishing Inc. This work is licensed under the Creative Commons Attribution International License (CC BY 4.0).

http://creativecommons.org/licenses/by/4.0/ (c) (i) Open Access

\begin{abstract}
Known deposits are appropriate sites for investigating significant exploratory keys that could be helpful in mineral exploration in corresponding regions or similar areas. This study was performed to delineate hydrothermal alteration model and some geophysical characteristics of the SarKuh porphyry copper deposit located within the southern part of the central Iranian Cenozoic magmatic belt (CICMB). Advanced Spaceborne Thermal Emission and Reflection Radiometer (ASTER) images have been used to produce hydrothermal alteration map using a fractal-aided spectral angle mapper (SAM) method. Airborne data were used to study magnetic-radiometric properties of the deposit. Image processing of ASTER images and laboratory studies proved the presence of two types of phyllic ale ration called intense and weak phyllic based on abundance of sericite mineral. It realized that radiometric anomalies of ${ }^{40} \mathrm{~K}$, eTh and eU are limited to boundary of phyllic zone. Radiometric ratios e.g. eTh $/{ }^{40} \mathrm{~K}$ were good enough to enhance phyllic zone.
\end{abstract}

\section{Keywords}

Porphyry Copper Deposit, Hydrothermal Alteration, ARTER, SAM, Airborne

Geophysics

\section{Introduction}

The SarKuh porphyry copper mine is situated within the southern part of the central Iranian Cenozoic magmatic belt (CICMB) in southeast of the Sarcheshmeh porphyry 
copper deposit (Figure 1(a)). CICMB has a great potential for hosting Tertiary porphyry copper deposits in Iran. Porphyry type deposits are associated with hydrothermal alterations such as phyllic, argillic, potassic and propylitic. The composition, mineralogy, and texture of rocks are changed during hydrothermal processes. These changes can be resulted in establishing different alteration zones that extend in vertical and lateral directions for kilometers. Hydroxyl minerals are abundant in the phyllic, argillic and potassic zones. At the same time, an oxide zone is developing over many of the porphyry bodies, which are rich in iron oxide minerals. These alteration minerals can be detected by remote sensing techniques [1]-[8]. Short wavelength infrared (SWIR) images of the Advanced Spaceborne Thermal Emission and Reflection Radiometer (ASTER) have been used successfully for hydrothermal alteration mapping in recent years in the southern part of the CICMB [3]-[8].

Variation in geophysical response of alteration zones is a fundamental measure that is used in exploration of porphyry copper deposits. This zonality exhibits magnetic properties which can be detected through aeromagnetic surveys [9]-[11]. Hydrothermal alteration minerals contain ${ }^{40} \mathrm{~K}$, which is associated with $\mathrm{K}$ during the hydrothermal processes, and is therefore an important component of fluids. Therefore, hydrothermal alteration minerals (sericite, biotite, K-feldspars and many K-bearing clay minerals) can be detected and mapped by using radiometric data [10]-[12]. Elevated potassium in the sericite zone is often observed around the mineralization areas and also acid sulfate conditions resulting from weathering of near surface sulfides can result in eTh mobilization from host rocks and can precipitate with iron in gossan [13]. Several workers

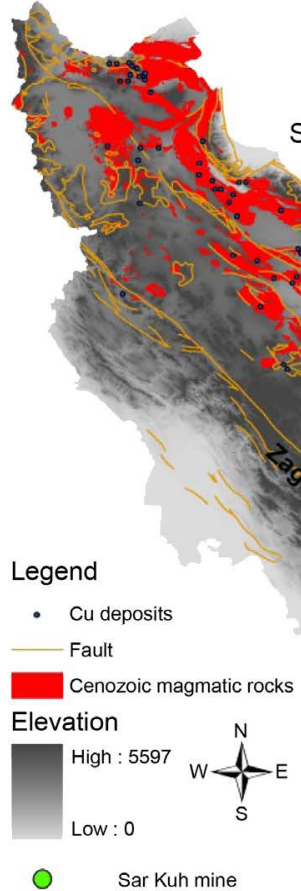

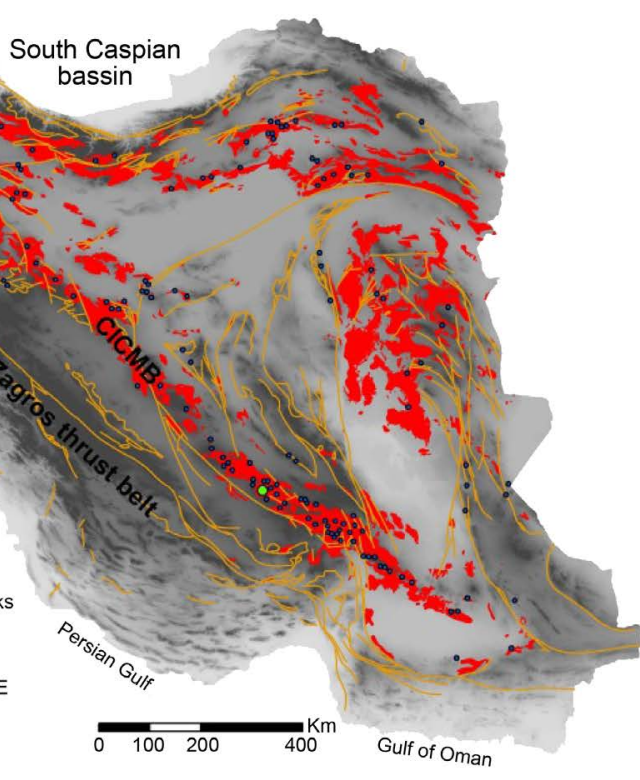

(a)

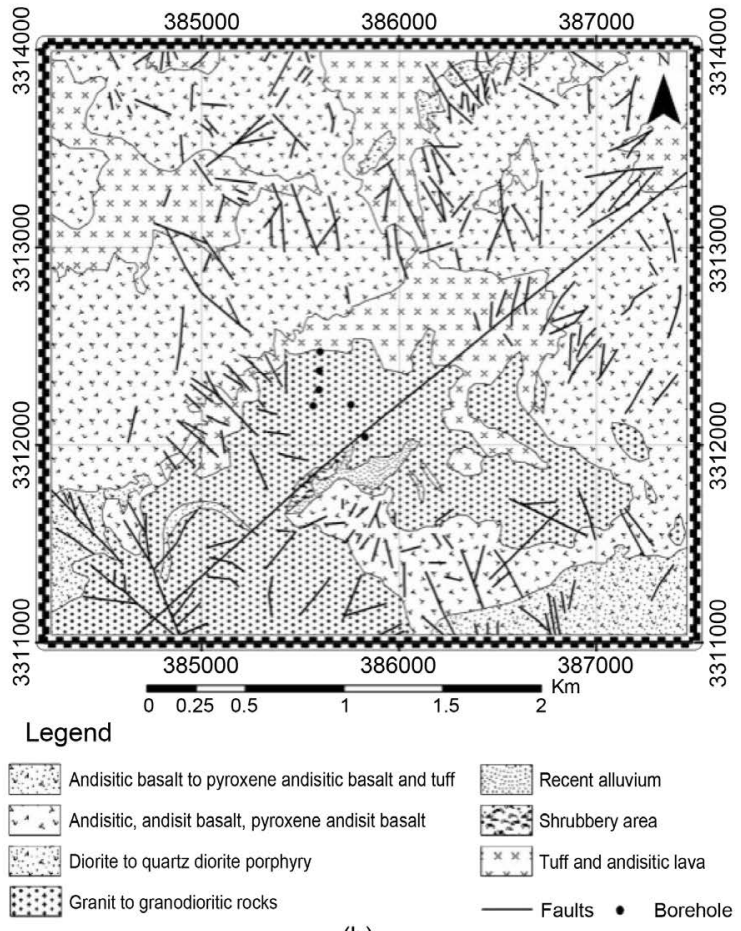

(b)

Figure 1. (a) The position of central Iranian cenozoic magmatic belt (CICMB); (b) Simplified geological map of the study area [16]. 
have reported a decrease in magnetization and changes in ${ }^{40} \mathrm{~K}$ and the ${ }^{40} \mathrm{~K} / \mathrm{eTh}$ ratio associated with hydrothermally altered zones [12], [14]. In addition, the application of gamma-ray spectrometry for the recognition of potassic alteration by using the $\mathrm{eTh} /{ }^{40} \mathrm{~K}$ ratio was reported [15].

The CICMB hosts porphyry copper deposits and is one of the main copper-bearing regions in the world, with great potential for Cenozoic porphyry copper mineralization. The southern part of the belt is considered as a rich region which contains familiar deposits such in Sarcheshmeh, Darrehzar, Nowchun, Sar-Kuh. Although, geophysical characteristics of these deposits are assumed to be similar, it is possible to have some differences. The present study aims to increase our knowledge about geophysical characteristic and its relationship to hydrothermal alteration of the Sar-Kuh porphyry copper deposit. Thus, it helps to take another step to define a more complete exploration model for porphyry copper deposit in southeast of (CICMB). To achieve this goal, images of ASTER sensor are used to map hydrothermal alteration and data of a helicopter magnetic/electromagnetic/radiometric survey (HMER) acquired in 1990 by Geonex Aerodat in the Kerman Province are utilized to investigate magnetic and radiometric properties of the Sar-Kuh porphyry copper deposit.

\section{Geological Setting}

The Sar-Kuh porphyry copper deposit is located in the Kuh-e-Mamzar ridge, about 6 $\mathrm{km}$ west of Sarcheshmeh porphyry copper deposit. The geology is relatively simple. The rocks consist of the upper Eocene volcanic-sedimentary complex, intruded by the large Kuh-e-Mamzar pluton. Minor portions of the area are covered by Quaternary deposits [16]. The intrusive rocks in the Sar-Kuh area represent the northern part of the large and petrologically complex Kuh-e-Mamzar pluton. Hydrothermal alteration has taken place mainly in the peripheral parts of the intrusive. The alterations consist of sericitization and argillization of feldspars; the dark minerals are chloritized and carbonatized, infrequently epidotized [16]. Figure 1(b) shows simplified geological map of the study area.

\section{Materials and Methods}

\subsection{Sattelite Images and Image Processing Method}

Level-1B (radiance at sensor) and cloud free ASTER images, acquired on 25 July 2001 were selected for this study. Pre-processing stage was applied using crosstalk correction using the crosstalk correction software (CCS), atmospheric correction using fast lineof-sight atmospheric analysis of spectral hypercubes (FLAASH) software and modification of unusually low reflectance for ASTER band 5 [2], [6], [17], [18]. The images were georeferenced to Universal Transverse Mercator (UTM) zone 40 North projection with the World Geodetic System 1984 (WGS-84) as datum, using ground control points from Google Earth ${ }^{\oplus}$ high resolution images. ASTER SWIR bands are positioned to define absorption features of common minerals that are typically formed by hydrothermal alteration processes (Figure 2). 


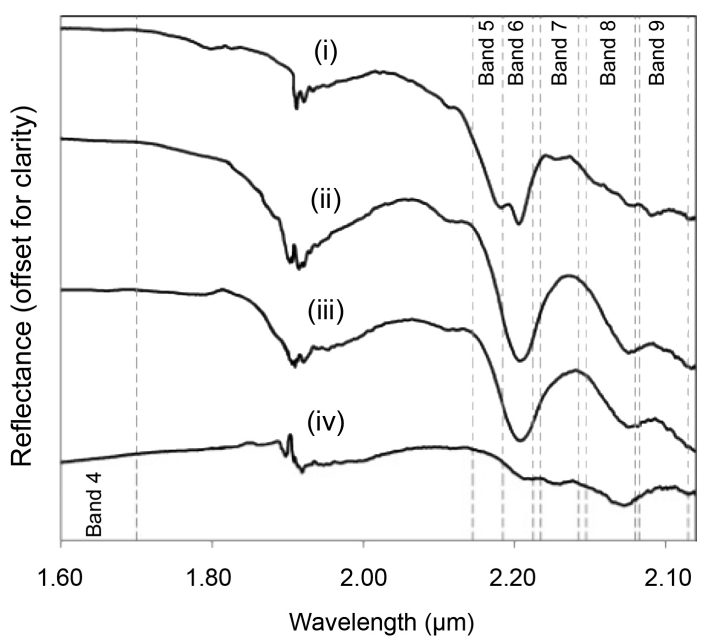

Figure 2. Representative spectra measured from different alteration zones in the southern part of the CICMB. (i) Argillic spectrum from Seridune prospect; (ii) Intense phyllic spectrum from Seridune prospect; (iii) Intense phyllic spectrum from Sarcheshmeh mine; (iv) Propylitic spectrum from Seridune prospect. SWIR bandwidths of ASTER sensor are shown on the figure.

Based on Figure 2, clay minerals in argillic zone show a strong absorption in band 6 and a shoulder in band 5. Muscovite (sericite) in phyllic alteration zone displays a strong absorption in band 6 and reflections in bands 5 and 7. Propylitic assemblage that contains mainly chlorite and minor amount of epidote shows a strong absorption in band 8 and reflections in band 7 and 9 of ASTER (Figure 2). Given the characteristic spectral features of alteration minerals in the ASTER SWIR bands, only bands 4 to 9 were utilized for spectral analysis using spectral angle mapper (SAM) method. The method facilitates a rapid image classification based on calculation of the angle between image spectra and reference spectra. SAM compares angle between the reference spectrum and each pixel spectrum vector in n-dimensional space, such that smaller angles represent better matches between the two spectral sets [19]. The angle is the arc-cosine of the dot product of the two spectra which is calculated based on Equation (1).

$$
\alpha=\cos ^{-1}\left(\frac{\sum_{i=1}^{n b} i_{i} r_{i}}{\left(\sum_{i=1}^{n b} i_{i}^{2}\right)^{1 / 2}\left(\sum_{i=1}^{n b} r_{i}^{2}\right)^{1 / 2}}\right)
$$

where $i_{i}$ and $r_{i}$ are image and reference spectra respectively and $n b$ is the number of bands. Each output class contains a set of pixels with spectral angle below a user-defined threshold angle (in radians) [19].

The accuracy of classification of the Spectral Angle Mapping (SAM) is warranted by choosing the appropriate threshold angles, which are normally defined by the user. Trial-and-error and statistical methods are commonly applied to determine threshold angles. The fractal-aided SAM method can determine less biased threshold angles for SAM classification of multispectral images [7], [8]. In this research, threshold angle for each reference spectra was determined based on RV-A fractal technique [7], [8]. Figure 3 presents the procedure of fractal-aided SAM method. Reference spectra of hydro- 
thermally-altered rocks were collected for SAM classification using the spectral digital number (DN)-profiles from known locations in hydrothermal alteration zones in the study area (Figure 4(a)). In fractal-aided SAM method, the first break in RV-A fractal curve defines the value of threshold angle for supposed spectrum (Figure 4(b)).

\subsection{Specifications of Airborne Geophysical Dataset}

Geonex Aerodat Incorporated, on behalf of the Iranian National Copper Company,

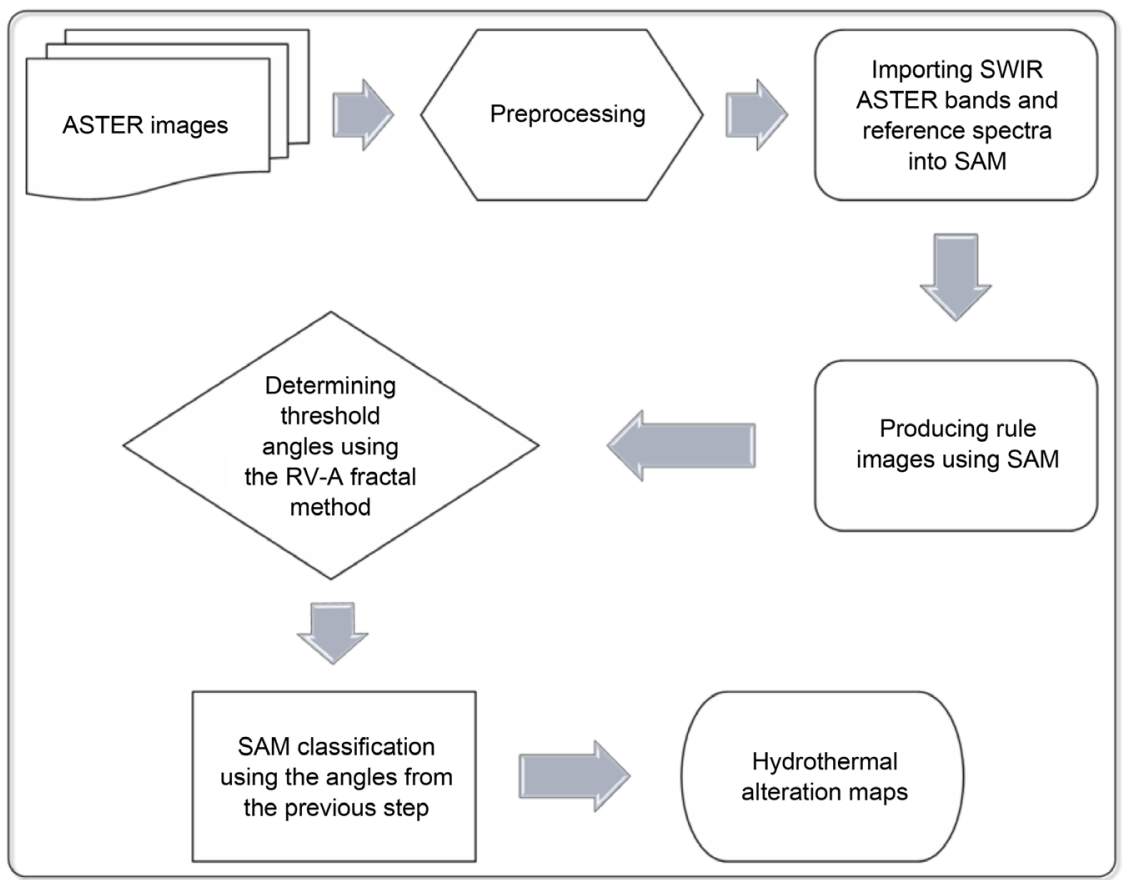

Figure 3. The procedure of SAM classification using less biased threshold angle(s) produced by RV-A fractal model [8].

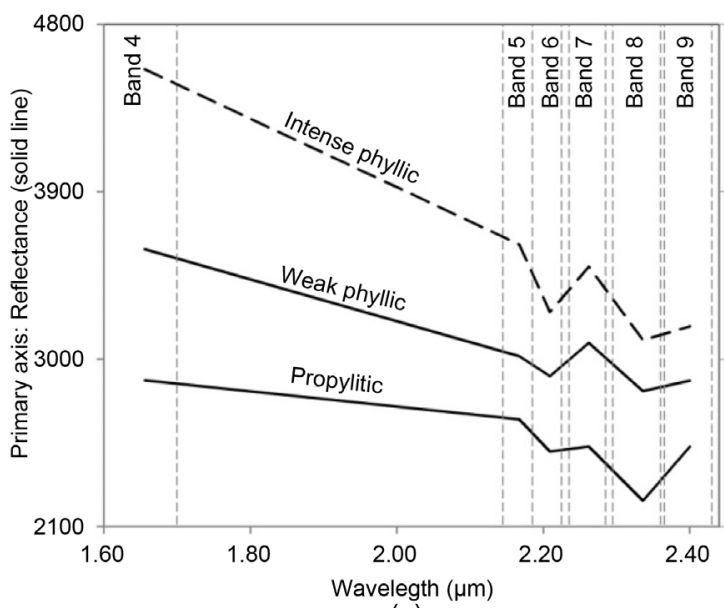

(a)

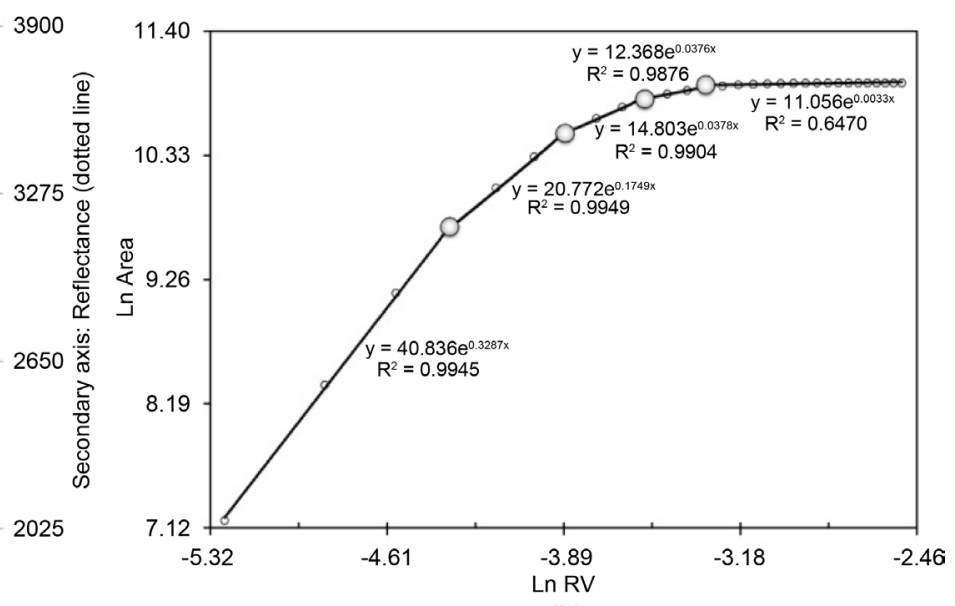

(b)

Figure 4. (a) Reference spectra of major hydrothermal alteration zones extracted from ASTER images of Sar-Kuh area (ASTER band's widths are shown on the figure); (b) An example of RV-A fractal curve that was used for calculating threshold angle of weak phyllic spectrum in Sar-Kuh area. 
conducted a helicopter magnetic/electromagnetic/radiometric (HMER) survey over an area of $7000 \mathrm{~km}^{2}$ in Kerman Province in 1990 [10], [11]. The aim of the survey was mainly to explore porphyry and vein-type mineralization in the Kerman region. The survey was conducted at $200 \mathrm{~m}$ flight spacing and constant altitude over an average topographic elevation of $60 \mathrm{~m}$ for the spectrometer, $45 \mathrm{~m}$ for the magnetometer and $30 \mathrm{~m}$ for the electromagnetic coils. Data were processed by various filtering and enhancement techniques for noise removal and data correction [20].

The total magnetic intensity map was prepared using reduced-to-pole (RTP) method. Ratio maps e.g. ${ }^{40} \mathrm{~K} / \mathrm{eTh}$, eTh/ ${ }^{40} \mathrm{~K}$ and also Equation (2) and Equation (3) obtained from reference [21] were used to delineate the presence of hydrothermal alteration.

$$
\mathrm{K}_{d(\text { cell })}=\left[{ }^{40} \mathrm{~K}_{\text {counts }(\text { cell })}-\mathrm{K}_{i(\text { cell })}\right] / \mathrm{K}_{i(\text { cell })}
$$

where

$$
\mathrm{K}_{i(\text { cell })}=\left[{ }^{40} \mathrm{~K}_{\text {counts(mapave. })}-\mathrm{Th}_{\text {counts(mapave. })}\right] / \mathrm{Th}_{\text {counts(cell) }}
$$

\subsection{Validation of Results}

Validation of results was undertaken through field observations, global positioning system (GPS) readings, collection of samples for thin section studies and XRD analysis (to determine the concentrations of clay minerals). The spectra of representative samples from hydrothermal alteration zones were measured using a Field Spec ${ }^{\circledR}$ spectroradiometer. Spectral analysis was carried out for mineral recognition based on reference spectra from the USGS digital spectral library [22]. The methodology is schematically presented in Figure 5.

\section{Result and Discussion}

Hydrothermal alteration exhibits significant development in the Sar-Kuh area. Figure 6 exhibits hydrothermal alteration map of Sar-Kuh area. Hydrothermal alteration follows a concentric model that phyllic zone located in the center. Based on SAM results and laboratory studies, phyllic zone is divided into two parts. Intense phyllic zone forms

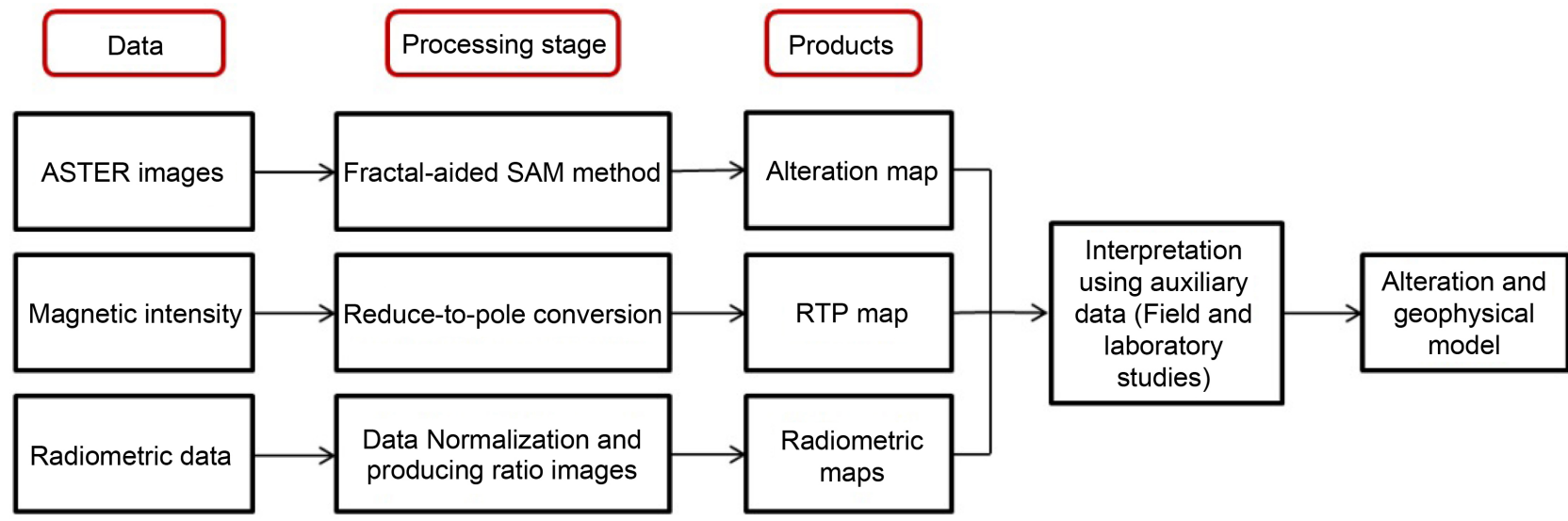

Figure 5. Schematic presentation of methodology. 


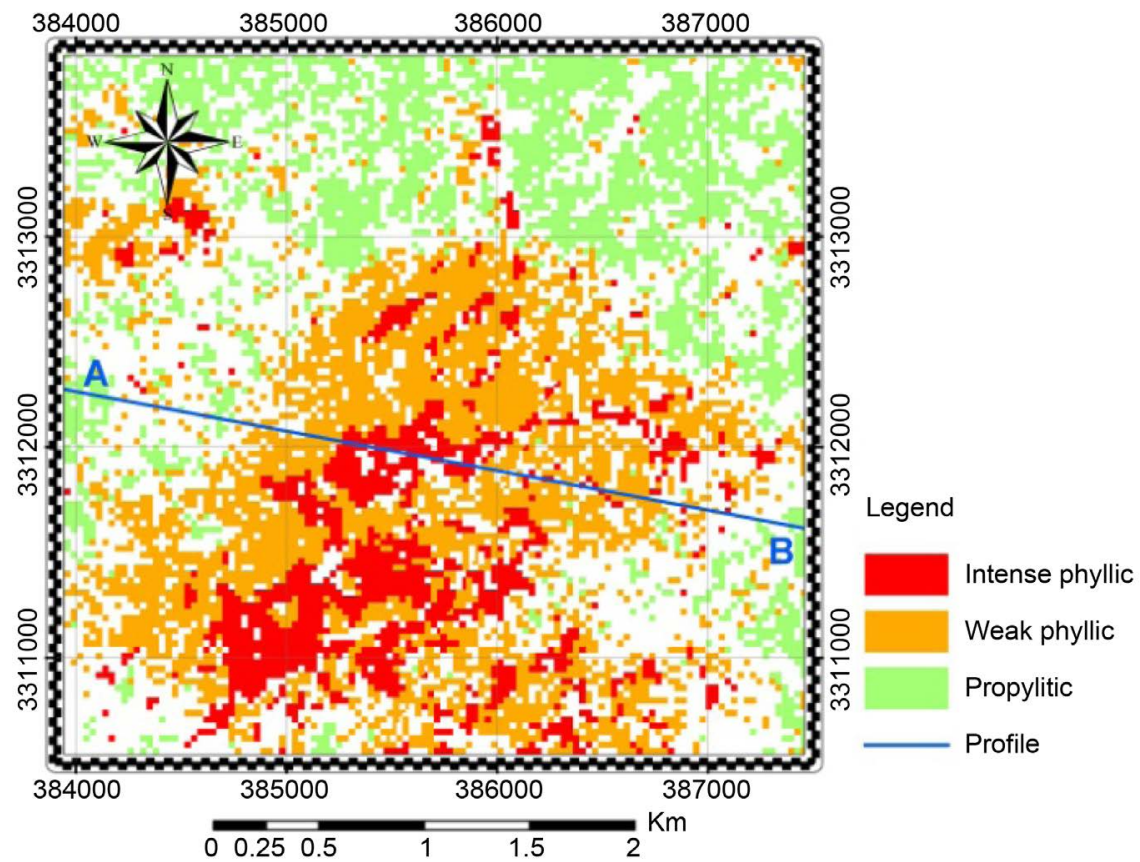

Figure 6. Hydrothermal alteration map of Sar-Kuh porphyry copper deposit by fractalaided SAM method.

central part surrounded by weak phyllic zone. Thin section studies proved that sericite is characterized with more abundance in the intense phyllic zone. According to Figure 6, propyllitic zone forms the outer zone that contains chlorite, epidote and calcite as typical minerals in propylitic zone. Argillic and potassic alteration were observed through field studies and laboratory works but were not enhanced using ASTER images due to their negligible extent.

Many hydrothermal alteration minerals contain ${ }^{40} \mathrm{~K}$, which is associated with $\mathrm{K}$ during the hydrothermal processes. ${ }^{40} \mathrm{~K}$ is responsible for most gamma radiation emitted by primary radioactive isotope of the Earth's crust [11], [20]. Therefore, hydrothermal alteration minerals (sericite, biotite, K-feldspars and many K-bearing clay minerals) can be mapped using radiometric data [11]. Figures 7(a)-(d) present radiometric anomalies of ${ }^{40} \mathrm{~K}, e \mathrm{Th}, \mathrm{eU}$, and total counts respectively that all of them obey phyllic alteration trend. According to Figure 7(c), eU anomaly is completely adjusted with boundary of phyllic alteration zone that is not common in other main deposits such as Sarcheshmeh and Darrehzar [23]. It means eU was not affected by hydrothermal processes to be mobilized. Figure 6, Figure 7(b), Figure 7(e), Figure 7(f), and Figure 7(g) can be compared to reveal that maximum values of $\mathrm{eTh}$ and $\mathrm{eTh} /{ }^{40} \mathrm{~K}$ and also minimum values of ${ }^{40} \mathrm{~K} / \mathrm{eTh}$ and $\mathrm{K}_{\mathrm{d}}$ are observed on the intense phyllic zone. Indeed, radiometric response of eTh that is stronger compared with ${ }^{40} \mathrm{~K}$ does not agree with previous studies in the region especially in the Sarcheshmeh porphyry copper deposit (Figure 7(e)).

Field observation revealed that weathering processes caused the magnetite content of the rocks to be changed into hematite (Figure 8). Figure 9 shows RTP magnetic map of the study area. Based on Figure 9, the vertical section along profile AB (Figure 6 and 

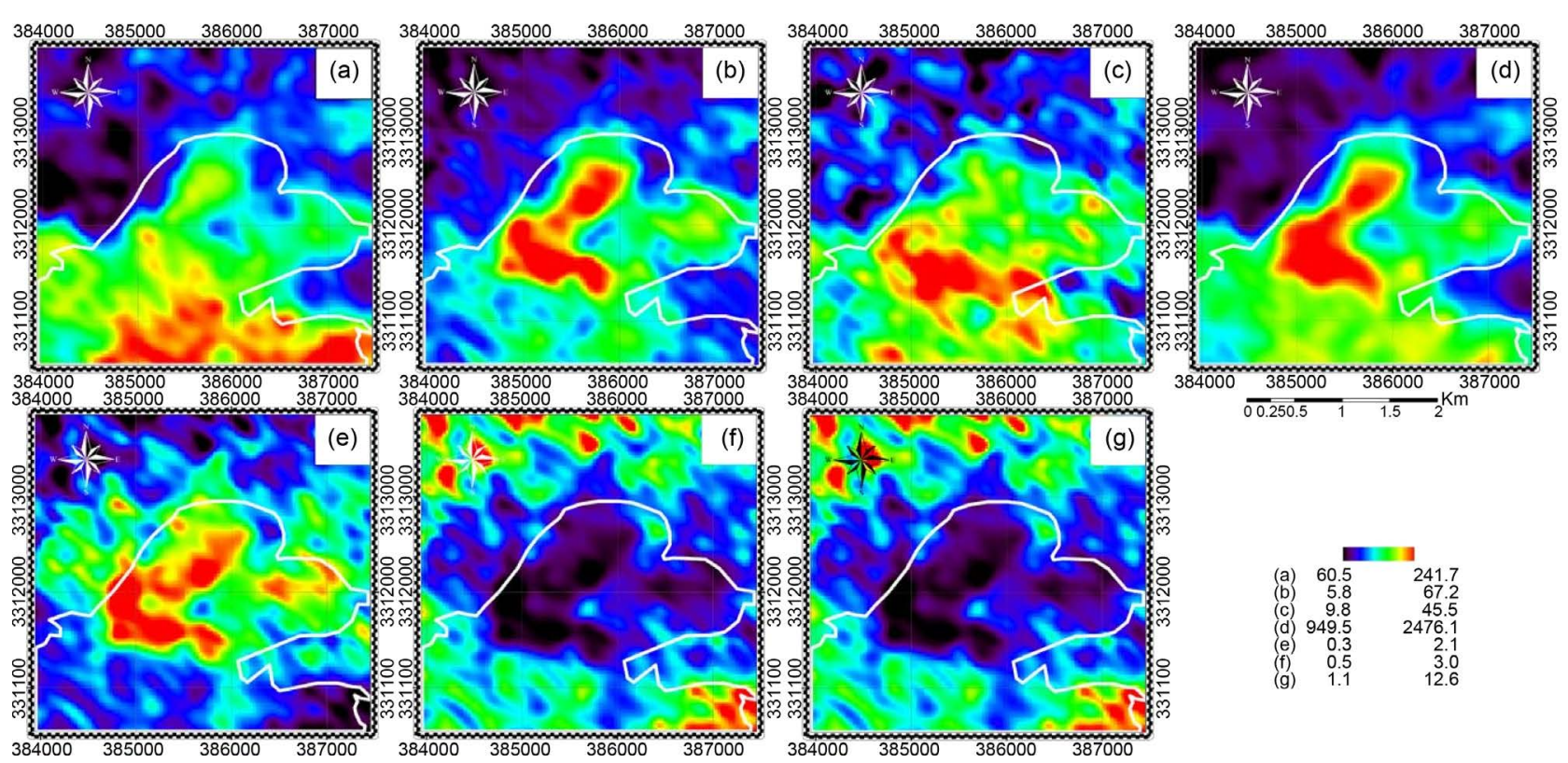

Figure 7. Distribution map of (a) ${ }^{40} \mathrm{~K}$, (b) eTh, (c) eU, (d) total counts, (e) Th/ ${ }^{40} \mathrm{~K}$, (f) ${ }^{40} \mathrm{~K} / \mathrm{Th}$, and $\mathrm{Kd}$ index in the Sar-Kuh area.
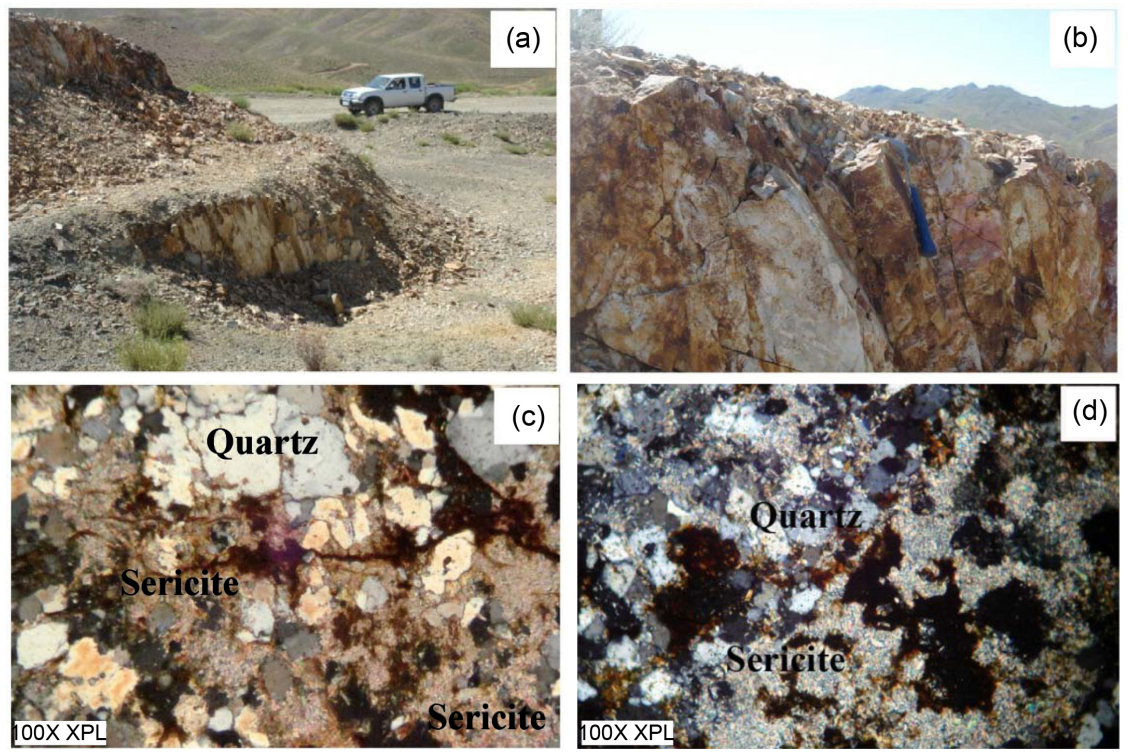

Figure 8. Weathering processes caused the magnetite content of the rocks to be changed into hematite in the Sar-Kuh area, (a) and (b) an outcrop of phyllic alteration, (c) and (d) thin section of phyllic alteration.

Figure 9) displays a gradually increase in susceptibility values from central phyllic zone towards surrounding propylitic zone. Polished and thin section studies showed that the content of magnetic in rock samples of propylitic zone is higher in comparison with phyllic alteration zone.

Typical decrease in reduced-to-pole total values of magnetic intensity on phyllic alteration in Figure 10 is comparable with hypothetical magnetic model defined for porphyry copper deposits (Figure 11). 


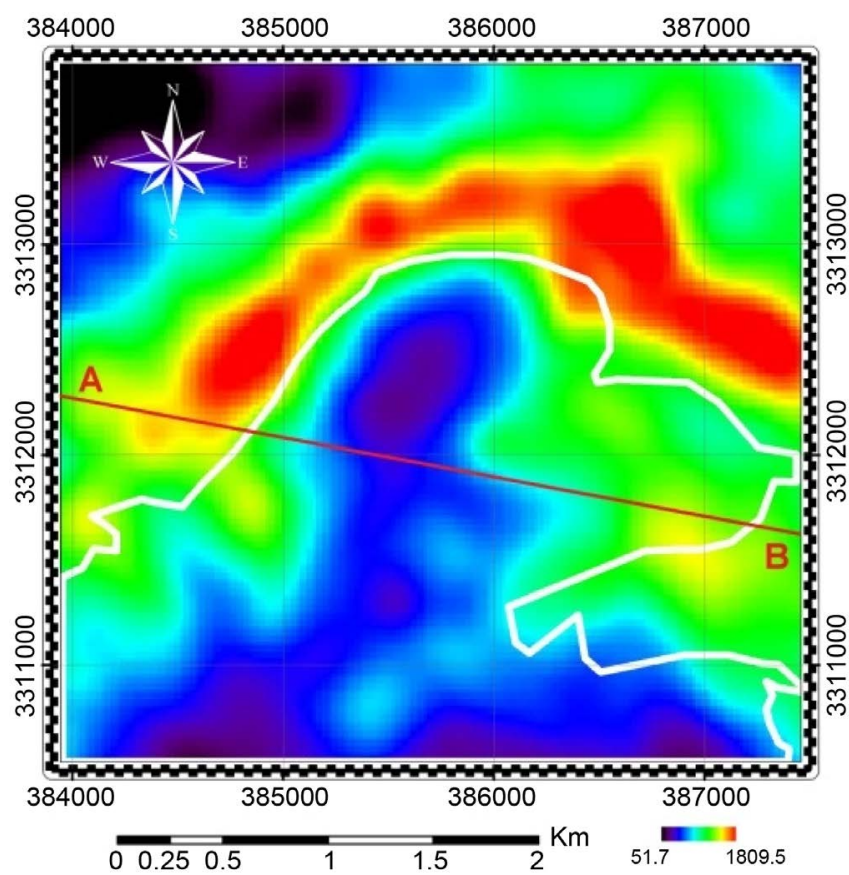

Figure 9. Reduce-to-pole (RTP) magnetic map of Sar-Kuh porphyry copper deposit.

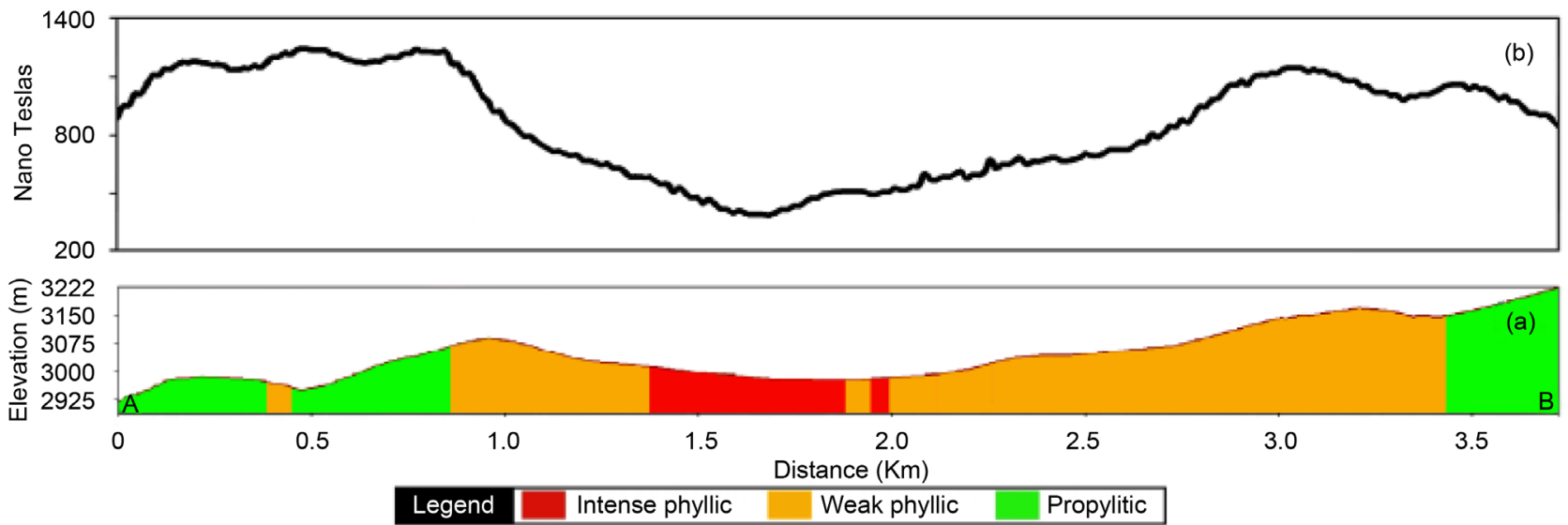

Figure 10. (a) Vertical section of hydrothermal alteration zone of Sar-Kuh area along profile AB in Figure 6; (b) Variation of magnetic intensity along profile $\mathrm{AB}$ in Figure 9.

\section{Summary and Conclusion}

This study was performed to investigate airborne and spaceborne geophysical properties of the Sar-Kuh porphyry copper deposit which can be applicable in exploration of porphyry copper deposits in the southern part of the CICMB. Hydrothermal alteration zones of the deposit follow theoretical concentric model defined for porphyry copper deposits. Image processing of ASTER SWIR bands using the fractal-aided SAM method leads to discriminating two different phyllic alterations called intense and weak phyllic based on abundance of sericite mineral. Thus, ASTER SWIR bands can be applied to map hydrothermal alteration with more details using the fractal-aided SAM method. 

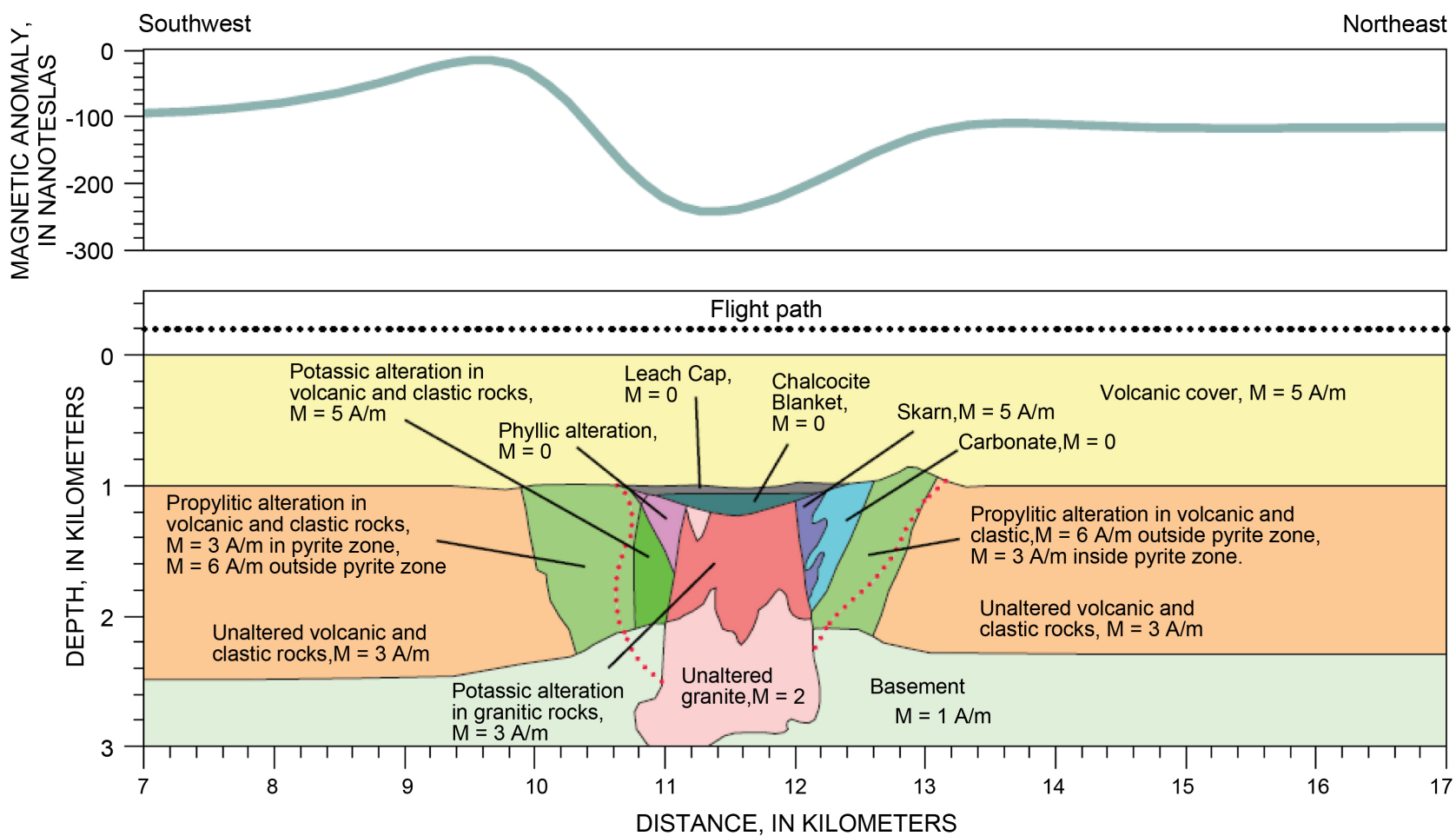

Figure 11. Magnetic anomaly caused by a hypothetical porphyry copper deposit. Text in the figure provides basic information regarding rock types and mineralization [9], [24].

Almost all airborne geophysical properties such as magnetic intensity, ${ }^{40} \mathrm{~K}$, and eTh anomalies were analogous with Sarcheshmeh and Darrehzar. But, a distinctive eTh anomaly is seen on intense phyllic zone that overcomes ${ }^{40} \mathrm{~K}$ anomaly that does not conform to other main porphyry copper deposits in the area. Thus, the probability of having high eTh and $e \mathrm{Th} /{ }^{40} \mathrm{~K}$ values or low ${ }^{40} \mathrm{~K} / \mathrm{eTh}$ and $\mathrm{K}_{\mathrm{d}}$ values must be taken into account in the exploration of porphyry copper deposit in the southern part of the CICMB.

\section{Acknowledgements}

I am grateful to the National Copper Industries Company (NICICo) of Iran for providing the geophysical data and the necessary facilities for field checking and sampling.

\section{References}

[1] Honarmand, M., Ranjbar, H. and Moezifar, Z. (2002) Integration and Analysis of Airborne Geophysics, Remote Sensing and Geochemical Data of Sar Cheshmeh Area, Using Directed Principal Component Analysis. Exploration and Mining Geology, 11, 43-48. http://dx.doi.org/10.2113/11.1-4.43

[2] Mars, J.C. and Rowan, L.C. (2006) Regional Mapping of Phyllic and Argillic Altered Rocks in the Zagros Magmatic Arc, Iran, Using Advanced Spaceborne Thermal Emission and Reflection Radiometer (ASTER) Data and Logical Operator Algorithms. Geosphere, 2, 161186. http://dx.doi.org/10.1130/GES00044.1

[3] Honarmand, M., Ranjbar, H. and Shahabpour, J. (2011) Application of Spectral Analysis in 
Mapping Hydrothermal Alteration of the Northwestern Part of the Kerman Cenozoic Magmatic Arc, Iran. Journal of Sciences, Islamic Republic of Iran, 22, 221-238.

[4] Honarmand, M., Ranjbar, H. and Shahabpour, J. (2012) Application of Principal Component Analysis and Spectral Angle Mapper in the Mapping of Hydrothermal Alteration in the Jebal-Barez Area, Southeastern Iran. Resource Geology, 62, 119-139.

http://dx.doi.org/10.1111/j.1751-3928.2012.00184.x

[5] Honarmand, M., Ranjbar, H. and Shahabpour, J. (2013) Combined Use of ASTER and ALI Data for Hydrothermal Alteration Mapping in the Northwestern Part of the Kerman Magmatic Arc, Iran. International Journal of Remote Sensing, 34, 2023-2046.

http://dx.doi.org/10.1080/01431161.2012.731540

[6] Shahriari, H., Ranjbar, H. and Honarmand, M. (2013) Image Segmentation for Hydrothermal Alteration Mapping Using PCA and Concentration-Area Fractal Model. Natural Resources Research, 22, 191-206. http://dx.doi.org/10.1007/s11053-013-9211-y

[7] Shahriari, H., Ranjbar, H., Honarmand, M. and Carranza., E.J.M. (2014) Selection of Less Biased Threshold Angles for SAM Classification Using the Real Value-Area Fractal Technique. Resource Geology, 64, 301-315. http://dx.doi.org/10.1111/rge.12042

[8] Shahriari, H., Ranjbar, H. and Honarmand, M. (2015) Comparison of Multi-Temporal ASTER Images for Hydrothermal Alteration Mapping Using a Fractal-Aided SAM Method. International Journal of Remote Sensing, 36, 1271-1289. http://dx.doi.org/10.1080/01431161.2015.1011352

[9] Phillips, J.D. (1998) Processing and Interpretation of Aeromagnetic Data for the Santa Cruz basin-Patagonia Mountains Area, South-Central Arizona. U.S. Geological Survey OpenFile Report 2002-98. http://geopubs.wr.usgs.gov/open-file/of02-98

[10] Ranjbar, H., Hassanzadeh, H., Torabi, M. and Ilaghi, O. (2001) Integration and Analysis of Airborne Geophysical Data of the Darrehzar Area, Kerman Province, Iran, Using Principal Component Analysis. Journal of Applied Geophysics, 48, 33-41.

http://dx.doi.org/10.1016/S0926-9851(01)00059-3

[11] Ranjbar, H., Masoumi, F. and Carranza, E.J.M. (2011) Evaluation of Geophysics and Spaceborne Multispectral Data for Alteration Mapping in the Sar Cheshmeh Mining Area, Iran. International Journal of Remote Sensing, 32, 3309-3327. http://dx.doi.org/10.1080/01431161003745665

[12] Airo, M.L. (2002) Aeromagnetic and Aeroradiometric Response to Hydrothermal Alteration. Surveys in Geophysics, 23, 273-302. http://dx.doi.org/10.1023/A:1015556614694

[13] Dickson, B.L., Fraser, S.J. and Kinsey-Henderson, A. (1996) Interpreting Aerial GammaRay Surveys Utilizing Geomorphological and Weathering Models. Journal of Geochemical Exploration, 57, 75-88. http://dx.doi.org/10.1016/S0375-6742(96)00017-9

[14] Dickson, B.L. and Scott, K.M. (1997) Interpretation of Aerial Gamma-Ray Surveys-Adding the Geochemical Factors. Journal of Australian Geology and Geophysics, 17, 187-200.

[15] Shives, R.B.K., Charbonneau, B.W. and Ford, K.I. (2001) The Detection of Potassic Alteration by Gamma-Ray Spectrometry-Recognition of Alteration Related to Mineralization. Geophysics, 65, 2001-2011. http://dx.doi.org/10.1190/1.1444884

[16] Nedimovic, R. (1973) Exploration for Ore Deposits in Kerman Region. Report No. 53, Geological Survey of Iran Publication, Tehran.

[17] Iwasaki, A. and Tonooka, H. (2005) Validation of a Crosstalk Correction Algorithm for ASTER/SWIR. IEEE Transactions on Geoscience and Remote Sensing, 43, 2747-2751. http://dx.doi.org/10.1109/TGRS.2005.855066

[18] Matthew, M.W., Adler-Golden, S.M., Berk, A., Richtsmeier, S.C., Levine, R.Y., Bernstein, 
L.S., Acharya, P.K., Anderson, G.P., Felde, G.W., Hoke, M.P., Ratkowski, A., Burke, H.H., Kaiser, R.D. and Miller, D.P. (2000) Status of Atmospheric Correction Using a MODTRAN4Based Algorithm. Proceedings of Algorithms for Multispectral, Hyperspectral, and Ultraspectral Imagery, 4049, 199-207. http://dx.doi.org/10.1117/12.410341

[19] Kruse, F.A., Lefkoff, A.B., Boardman, J.B., Heidebreicht, H.K.B., Shapiro, A.T., Barloon, P.J. and Goetz, A.F.H. (1993) The Spectral Image Processing System (SIPS)-Interactive Visualization and Analysis of Imaging Spectrometer data. Remote Sensing of Environment, 44, 145-163. http://dx.doi.org/10.1016/0034-4257(93)90013-N

[20] De Quadros, T.F.M., Koppe, J.C., Strieder, J.C. and Costa, J.F.C.L. (2003) Gamma-Ray Data Processing and Integration for Lode-Au Exploration. Natural Resources Research, 12, 5765. http://dx.doi.org/10.1023/A:1022608505873

[21] Reford, S.W. and Paterson, N.R. (1994) Airborne Geophysical Survey in Weathered Terrain. In: Bloom, L., Ed., Prospecting in Tropical and Arid Terrains, Prospectors and Developers Association of Canada, Ontario, 61-109.

[22] Clark, D.A. (1999) Magnetic Petrology of Igneous Intrusions, Implications for Exploration and Magnetic Interpretation. Exploration Geophysics, 20, 5-26.

http://dx.doi.org/10.1071/EG999005

[23] Shahriari, H. (2014) Proposing an Exploratory Model for Porphyry Type Copper Mineralization in the Central Region of Kerman Cenozoic Magmatic Arc. Unpublished PhD Thesis, Shahid Bahonar University of Kerman, Kerman.

[24] John, D.A., Ayuso, R.A., Barton, M.D., Blakely, R.J., Bodnar, R.J., Dilles, J.H., Gray, F., Graybeal, F.T., Mars, J.C., McPhee, D.K., Seal, R.R., Taylor, R.D. and Vikre, P.G. (2010) Porphyry Copper Deposit Model, Chapter B of Mineral Deposit Models for Resource Assessment. US Geological Survey Scientific Investigations Report 2010-5070-B.

\section{Submit or recommend next manuscript to SCIRP and we will provide best service for you:}

Accepting pre-submission inquiries through Email, Facebook, LinkedIn, Twitter, etc. A wide selection of journals (inclusive of 9 subjects, more than 200 journals)

Providing 24-hour high-quality service

User-friendly online submission system

Fair and swift peer-review system

Efficient typesetting and proofreading procedure

Display of the result of downloads and visits, as well as the number of cited articles

Maximum dissemination of your research work

Submit your manuscript at: http://papersubmission.scirp.org/

Or contact ojg@scirp.org 